\title{
ZAPOWIEDŹ PRZYJŚCIA ZBAWICIELA W IV EKLODZE WERGILIUSZA
}

Publiusz Wergiliusz Maro (70-19 prz. Chr.), największy epik rzymski (Eneida), pochodził z wioski Andes pod Mantuą. Owocem życia na wsi stała się twórczość bukoliczna. Zaczął pisać na wzór Teokryta (pocz. III w. prz. Chr.) w 42 roku. Nie tłumaczył go na łacinę, ale przejmował od niego motywy, tworząc nowe kompozycje łacińskie. W roku 39 ogłosił w Rzymie zbiór dziesięciu sielanek (Bucolica, Eclogae) - pieśni pasterskich, napisanych na życzenie $^{1}$ Gajusza Azyniusza Polliona (76 prz. Chr. -4 po Chr.), swojego przyjaciela, mówcy, poety, historyka, dowódcy i męża stanu, który w wojnie domowej stanął po stronie Gajusza Juliusza Cezara (100-44 prz. Chr.); w r. 43 przyłączył się do Marka Antoniusza, doprowadzając do zgody między nim a Oktawianem (63 prz. Chr. - 14 po Chr.) w układzie w Brundyzjum 40 r. prz. Chr. i w tym samym roku objął konsulat. Temuż Pollionowi poświęcił Wergiliusz słynną IV eklogę, która powstała w 40 roku. Trzydziestoletniego Wergiliusza uważano już w 39 r. za pierwszego poetę w Rzymie, a jego IV ekloga mesjańska, jak pisał T. Sinko, ,zdawała się inaugurować nie tylko nową epokę literatury, ale także odnowienie świata", odnowienie przede wszystkim moralne, do jakiego dążył już od 36 r. Oktawian, sądząc że trwały pokój i nowy porządek rzeczy nie zapanuje w Rzymie, dopóki będą coraz to nowe rewolucje i przewroty polityczne, a ludzie nie wyrzekną się żądzy bogactw i nie wrócą do dawnych prostych obyczajów starorepublikańskich i do cnót ojców ${ }^{2}$.

Ekloga IV - to tajemniczy utwór. Wergiliusz zawdzięcza mu swoje miano proroka i mędrca. Poeta jak najbardziej świadomie oddala się w nim od Teokryta. By łatwiej zrozumieć jego treść, przytoczymy go w całości w przekładzie Z. Abramowiczówny:

\footnotetext{
${ }^{1}$ Por. Ecloga VIII 11-12:

,... accipe iussis carmina coepta tuis ...".

${ }^{2}$ Por. Wstęp, w: Wergiliusz, Eneida, tłum. T. Karyłowski SJ, wstępem i komentarzem opatrzył T. Sinko, wyd. 2 zmienione, BN II 29, Wrocław 1950, ss. XVI-XVII.
} 
„Muzy sycylskie, spróbujmy i wyższe rzeczy opiewać.

Niskie zarośla i mdłe tamaryszki nie wszystkich zachwycą;

Jeśli las opiewamy, niech godny on będzie konsula!

Oto ostatni się czas kumejskiej pieśni pojawił,

5 Oto na nowo się wieków odradza wielki porządek,

Już Dziewica powraca, powraca królestwo Saturna,

Nowy potomek z niebios wysokich na padól zstępuje.

Ty jedynie dziecięciu, co rodzi się - aby żelazne

Znikło plemię, a złote na całym świecie rozbłysło -

${ }^{10}$ Sprzyjaj, czysta Lucyno; Apollo już, brat twój panuje.

Pollio, za twego to dziś konsulatu poczyna się chwała

Wieku naszego i wielkie miesiące w bieg swój wstępują.

Znikną pod twoją wodzą, jeżeli zostały; występków

Naszych ślady, i świat od wiecznej trwogi uwolnią.

15 On zaś żywot od bogów uzyszcze i ród bohaterów

Ujrzy pomiędzy niebiany i sam wśród nich się ukaże,

W cnoty strojny ojcowskie, w pokoju władnąc nad światem.

Tobie, o dziecię, ziemia przyniesie pierwsze podarki:

Pnący się bluszcz samorzutnie wyda i kwiat naparstnicy,

${ }^{20}$ Oraz wśród hożych akantów nenufar zrodzi egipski.

Same kozy przyniosą do domu mleczne wymiona

Pełne, a lwa ogromnego nie będą lękały się stada.

Sama kołyska tobie kwiatami nowymi zakwitnie,

Wąż jadowity zginie i zginie podstępnie trujące

25 Ziele; powszędy róść asyryjski balsam ci będzie.

Skoro zaś tylko zaczniesz poznawać cnót bohaterów

Chwałę i czyny rodzica, i czym jest wielkość, rozumieć.

Niwy wiotkimi kłosy pomału poczną się złocić,

Słodkie grona rumiane na dzikich głogach zawisną.

${ }^{30} \mathrm{Z}$ twardych zaś dębów miód rosisty sączyć się będzie.

Jeszcze jednakże niejakie pierwotnych błędów zostaną

Ślady, co każą pruć okrętom łono Tetydy,

Miasta murami otaczać i bruzdy w roli prowadzić.

Nowy naonczas Tyfis się znajdzie i nowa też Argo

35 Łódź bohaterów wybranych wioząca. I wojny podobne.

Znowu z wyprawą pod Troję wyruszy wielki Achilles.

Kiedy zaś wreszcie okrzepną ci lata i mężem uczynią.

Również i żeglarz morza porzuci, a nawa sosnowa

Wieźć ku wymianie towarów nie będzie, bo ziemia każdemu

40 Wyda wszystko, co trzeba, bez trudu motyki i sierpa;

Krzepki oracz już woły spod jarzma na karku uwolni,

Wełna oduczy się barwność kłamanym udawać kolorem.

Sam bo baran na łące odmieni swe runo i już to

Krasą purpury, już to szafranem złocistym zabłyśnie,

45 Pąs samorzutnie zaś wełnę okryje jagniąt na paszy.

- „Kręćcie się, kręćcie przez takie stulecia!” do wrzecion swych rzekły

Parki, zgodne w wieczystym porządku boskich przeznaczeń. 
Sięgnij-że już po wysokie godności - boć pora nadchodzi Bogów najmilsze dziecię, Jowisza wielki potomku.

50

Patrz na bryłę wszechświata wzruszoną w swoich posadach,

Lądy, morza, otchłanie, bezdenną niebios głębinę,

Patrz, jak wszystko dokoła z przyszłego się wieku raduje.

Obyż mi życia tak długo ostatnie ciągnęły się lata,

Obyż i ducha starczyło - bym zdążył wysłowić twe czyny!

55 Ani mnie tracki Orfeusz pieśniami pokonać nie zdoła,

Ani Linus: choć ojciec i matka z pomocą im przyjdą:

Orfeuszowi Kaliope, Linowi nadobny Apollo.

Choćby i Pan szedł ze mną przed sądem Arkadii w zawody,

Pan pokonanym się uzna przed sądem Arkadii przeze mnie.

60 Zacznij, dziecino, po czułym uśmiechu matkę poznawać.

Wiele-ci zniosła matka przez dziesięć długich miesięcy.

Zacznij, dziecino! Do kogo rodzice nie śmieli się, tego

Bóg dopuścić nie raczy do stołu, do łoża bogini". 3

Na wstępie poeta wzywa, jak widać, Muzy sycylijskie do opiewania w tej samej formie bukolicznej treści nieco wznioślejszej (w. 1):

„Sicelides Musae, paulo maiora canamus!”

Nie występują tu żadni pasterze. Poeta przemawia przez cały czas sam. Kieruje apostrofy do Lucyny, boskiej opiekunki porodu, do Polliona i jakiegoś boskiego dziecięcia. Wergiliusz głosi w tej eklodze, jak objaśnia Z. Abramowiczówna we Wstępie do jej przekładu ${ }^{4}$, proroctwo o nadejściu chwili przełomowej. Świat ma się odrodzić za konsulatu Polliona, do którego poeta zwraca się z uwielbieniem, ponieważ wróci wtedy wiek złoty, narodzi się cudowne dziecię, któremu natura przyniesie dobrowolne dary, a gdy ono dorośnie, zniknie zło, cierpienie i trud, a świat będzie zażywać pokoju, sprawiedliwości ${ }^{5}$ i szczęśliwości. Ekloga kończy się wezwaniem, by dziecię nauczyło się po uśmiechu rozpoznawać matkę. Taka oto jest treść IV eklogi wyrażona stylem podniosłym i natchnionym. Od lat dyskutuje się, kim jest owo wymienione w IV eklodze dziecię ${ }^{6}$ ? Z. Abramowiczówna wskazuje na cztery spośród wielu interpretacji?

${ }^{3}$ Wergiliusz, Bukoliki i georgiki (wybór), przełożyła, wstępem opatrzyła i opracowała Z. Abramowiczówna, BN II 83, Wrocław 1953, 19-24.

${ }^{4}$ Por. tamże, ss. XXIII-XXIV.

5 Por. Ecloga IV 6: „iam redit et virgo” - „Już dziewica powraca”, to jest sprawiedliwość, która odeszła do nieba przed zbrodniami ludzi; zob. Georgica II 474.

${ }^{6}$ Por. R. S. Conway, Vergil's Messianic Eclogue, London 1907; H. Jeanmaire, Le Messianisme de Vergile, Paris 1930; J. Carcopino, Virgile et le mystère de la IV Eclogue, Paris 1930; R. Verdiere, De la tisane de Britannicus au berceau de l'enfant de la IV bucolique virgilienne, „Rivista di Studi Classici” 12(1964) 113-124; M. Manson, L'enfant et l'âge d'or. La IV eclogue de Virgile. Présence de Virgile, Paris 1978, 49-62; H. Naumann, Das Geheimnis der Vierten Ekloge, ,Der Altsprachliche Unterricht" 24(1981) Heft 5, 29-47 (streszczenie istniejących hipotez); W. Kraus, Vergils vierte Ekloge: ein kritisches Hypomnema, ANRW II 31.1 (1981) 604-645 (bibliografia do 1975 r.); 
1. dziecię jest alegorią (narodzin złotego wieku, pokoju, nowego Rzymu itp.);

2. jest jakąś boską istotą: z polskich badaczy pogląd ten reprezentuje T. Sinko ${ }^{8}$ : puer (w. 18, 60 i 62); ille deum vitam accipiet: „, On zaś żywot od bogów użyszcze” (w. 15); cara deum suboles, magnum Iovis incrementum!: „Bogów najmilsze dziecię, Jowisza wielki potomku" (w. 49); iam nova progenies caelo demittitur alto: „Nowy potomek z niebios wysokich zstępuje” (w. 7); ,nowy potomek" (w. 7) - to ów oczekiwany wybawiciel; ,on zaś” (w. 15), chłopiec według Abramowiczówny - to przyszły wybawiciel. W komentarzu zaś zaznacza, że „,chrześcijaństwo chciało w nim widzieć Chrystusa"; 9

3. jest ucieleśnieniem proroctw sybillińskich, przepowiadających ,wypełnienie się czasów" i powrót złotego wieku, czyli powrót królestwa boga Saturna, który panował w Lacjum w złotym wieku ${ }^{10}$, wieku mającego przypominać pierwotną równość rodu ludzkiego - T. Zieliński, jak zwraca na to uwagę Abramowiczówna, - ,widzi tu ucieleśnienie prądów mesjanistycznych nurtujących epokę, prądów wypływających ze źródła sybillińskiego, a zasilanych analogicznymi nurtami $w$ innych religiach i środowiskach cywilizacji greckorzymskiej. Zbliżony pogląd reprezentuje M. Popławski"11.

4. jest człowiekiem: przytaczane są w tej interpretacji różne postacie historyczne, z których przynajmniej część można uznać za mało wiarygodne (m.in. syn Polliona Asinus Gallus albo Saloninus, oczekiwane dziecko Oktawiana i Skribonii - Julia, syn Oktawii - Marcellus, dziecko Antoniusza i Kleopatry $)^{12}$. Problem dotąd nie został ostatecznie rozwiązany.

Utwór jednak jest przepojony, jak twierdzi Abramowiczówna, wiarą w nadejście jakiegoś przełomu. Po okrutnej przecież i długotrwałej epoce walk

J. Beaujeu, L'enfant sans nom de la IV $V^{e}$ Bucolique, REL 60(1982) 186-215; A. Uruschadse, Vergils vierte Ekloge, „Klio” 67(1985) 205-209; G. Pascucci, I versi finali della IV ecloga di Virgilio nell' interpretazione degli umanisti, w: Tradizione classica e letteratura umanistica. Festschrift di A. Perosa, Roma 1985, 507-523; J. M. Rodriguez Peregrina, La Egloga IV de Virgilio a través de la Interpretatio alegorica de Luis Vives, „Florentia Iliberritana. Granada” 2(1991) 455-466; B. Arnold, The literary Experience of Vergil's fourth Eclogue, ,The Classical Journal” 90(1994-1995) z. 2, 143-160; J. Ruiz Arzalluz, Augusto, Neron y el puer de la cuarta égloga, ,Aevum” 69(1990) 115-145; M. Petrini, The child and the hero: comming of age in Catullus and Vergil, An Arbor 1996.

${ }^{7}$ Por. Wstęp, w: Wergiliusz, Bukoliki i georgiki, dz. cyt., ss. XXIV-XXV.

${ }^{8}$ Por. wyżej n. 2.

${ }^{9}$ Por. Wstęp, w: Wergiliusz, Bukoliki i georgiki, dz. cyt., s. XXIV.

${ }^{10}$ Por. Aeneis VIII 319-321.

11 Por. Abramowiczówna, Wstęp, w: Wergiliusz, Bukoliki i georgiki, dz. cyt., s. XXV n. 4; T. Zieliński, Religia Rzeczypospolitej Rzymskiej, rozdz. IX, Warszawa 1934; M. Popławski, Mesjanistyczny poemat Wergiliusza, w: Commentationes Vergilianae, Cracoviae 1930, 244-430, też oddzielnie - Kraków 1930; K. Morawski, Historia literatury rzymskiej. Vergilius i Horatius, Kraków 1916, 58-61.

${ }^{12}$ Por. Abramowiczówna, Wstęp, w: Wergiliusz, Bukoliki i georgiki, dz. cyt., s. XXV; M. Cytowska - H. Szelest, Literatura rzymska. Okres augustowski, Warszawa 1990, 76-77. 
bratobójczych i wojen domowych oczekiwano wyraźnie w zmęczonym i utrudzonym ponad miarę społeczeństwie rzymskim ery pokoju, wytchnienia i sprawiedliwości. Czekano na przyjście jakiegoś wybawiciela z różnego rodzaju udręk i niesprawiedliwości. Podstawą tej wiary musiały być przede wszystkim przepowiednie ksiąg sybillińskich, które od wieków kierowały polityką Rzymu, a ponadto staroitalska pamięć o królestwie Saturna. „Jak głęboko owa wiara tkwiła w duszy samego poety, trudno powiedzieć"13.

M. Cytowska i H. Szelest wskazują również w swojej Literaturze rzymskiej na cztery interpretacje typu alegorycznego:

1. Dziecko jest wcieleniem Apollona lub Dionizosa albo Hermesa.

2. Jest urzeczywistnieniem przepowiedni Sybilli (Oracula Sibyllae) zapowiadającej nadejście złotego wieku w 40 r. przed Chrystusem.

3. Chłopiec z eklogi jest wyobrażeniem złotego wieku.

4. Chłopiec jest urzeczywistnieniem przepowiedni magów perskich, głoszących narodziny sprowadzającego szczęśliwe czasy dziecięcia ${ }^{14}$.

Przypominają także przy tym rzeczywistość, że „Wergiliusz znał rozpowszechnione w jego czasach wszelkiego typu przepowiednie i proroctwa mające swój początek w tradycji grecko-rzymskiej, jak i w wierzeniach ludów Judei, Egiptu i Persji" ${ }^{15}$. Cytowska i Szelest przytaczają także chrześcijańską interpretację, dopatrującą się w IV eklodze Wergiliusza zapowiedzi narodzin Jezusa Chrystusa, jaką zapoczątkował św. Augustyn, a była popularna aż do XVI wieku ${ }^{16}$; obecnie zaś, zdaniem autorek cytowanego podręcznika, nie budzi przekonania"17.

13 Abramowiczówna, Wstęp, w: Wergiliusz, Bukoliki i georgiki, dz. cyt., s. XXV.

${ }_{14}$ Por. M. Cytowska - H. Szelest, Literatura rzymska. Okres augustowski, dz. cyt., 77-78.

15 Tamże, s. 78; O wierzeniach Judei zob. R. Coleman, Vergile et le mystère de la IV Eclogue, Paris 1930, s. 133, który nawiązuje do Iz 7, 14; podobne proroctwo zob. Oracula Sybillae III 652.

${ }^{16}$ Jej dzieje przedstawia szczegółowo S. Benko: Virgil's Fourth Eclogue in Christian Interpretation, ANRW II 31.1, ss. 646-705; wcześniej zob. J. M. Pfättisch, Der prophetische Charakter der vierten Ekloge Vergils bis Dante, „Historisch-Politische Blätter” 139(1907) 637-646, 734-751; G. Edmann, Die Vorgeschichte des Lucas und Matthäusevangeliums und Vergils Vierte Ekloge, Göttingen 1932; H. Hommel, Vergils messianisches Gedicht, Berlin 1950; P. Courcelle, Les Exégèses chrétiennes de la quatrième Eclogue, REA 59(1957) 294-319; K. Morawski, Historia literatury rzymskiej. Vergilius i Horatius, dz. cyt., s. 61: „chrześcijańscy pisarze nie wahali się mimo tego ogłaszać Vergiliusa z jego czwartą eklogą za jednego z tych, którzy przepowiedzieli przyjście Chrystusa Pana i otoczyli wskutek tego pogańskiego poetę tym nimbem, który go Dantemu na przewodnika zalecił”; B. Luiselli, Il profetismo virgiliano nella cultura veterocristiana, „Sandalion” 6-7(1983-1984) 133-149; E. Gallicet, Virgilio nel mondo cristiano dei primi secoli, w: Vergilius Vaticanus Romanus, II, Roma 1986, 71-98; L. Nicastri, La quarta ecloga di Virgilio e la profezia dell'Emmanuele, „Vichiana” 18(1989) 221-261; W. Clausen, Virgil's messianic Eclogue, w: Poetry and Prophecy: the beginnings of a literary tradition, ed. J. Kugel, Ithaca 1990, 65-74; J. Van Sickle, A reading of Virgil's messianic Eclogue, New York 1992.

17 Cytowska - Szelest, Literatura rzymska, dz. cyt., s. 77. 
Chrześcijańska interpretacja św. Augustyna zawarta jest w jego Komentarzu do listu św. Pawła do Rzymian oraz w Liście 137 skierowanym do wybitnego poganina Woluzjana, urodzonego ok. 382 r. w bardzo dostojnej starożytnej rodzinie rzymskiej ${ }^{18}$.

Wspomniany komentarz św. Augustyna wyjaśnia m.in. wiersz (Rz 1,2) o powołaniu św. Pawła apostoła, przeznaczonego do głoszenia Ewangelii Bożej, którą Bóg przedtem zapowiedział przez swoich proroków:

„Jeżeli mianowicie z narodu żydowskiego byli prorocy (Siquidem de populo Iudaeorum fuerunt prophetae), przez których jest poświadczone, że Ewangelia (Evangelium), dzięki wierze w którą wierzący zostają usprawiedliwieni, była zapowiedziana przedtem (ante promissum esse testatur): «Przeznaczony» bowiem, mówi (apostoł), «do głoszenia Ewangelii Bożej» (in evangelium Dei), którą Bóg zapowiedział przedtem przez swoich proroków (quod ante promiserat per prophetas suos). Byli bowiem i nie Jego prorocy (Fuerunt enim et prophetae non ipsius), u których znajdują się także pewne zapowiedzi (in quibus aliqua inveniuntur), jakie ogłosiły usłyszane wiadomości o Chrystusie (quae de Christo audita cecinerunt), jak to jest mowa także o Sybilli (sicut etiam de Sibylla dicitur), w co niełatwo bym wierzył (quod non facile crederem), gdyby właśnie najznakomitszy z poetów w języku rzymskim (poetarum quidem in Romana lingua nobilissimus), zanim miał mówić (antequam deceret ea) o odnowieniu wieku (de innovatione saeculi) o tym, co zdaje się dostatecznie odnosić i pasować do królestwa naszego Pana, Jezusa Chrystusa (quae in domini nostri lesu Christi regnum satis concinere et convenire videtur), nie umieścił najpierw tego wiersza mówiąc:

«Oto ostatni się czas kumejskiej pieśni pojawił»

(Ultima Cumaei iam venit carminis aetas) ${ }^{19}$.

Nikt zaś nie będzie wątpił, że jest to jednak kumejska pieśń sybillińska ( $\mathrm{Cu}$ maeum autem carmen sibyllinum esse nemo dubitaverit). Apostoł więc wie (Sciens ergo apostolus), że te świadectwa prawdy znajdują się w księgach pogańskich (ea in libris gentium invenire testimonia veritatis), o czym mówiąc także w Dziejach Apostolskich (quod etiam in Actibus Apostolorum loquens) ${ }^{20}$ bardzo wyraźnie pokazuje Ateńczykom (Atheniensibus manifestissime ostendit), nie tylko mówi «przez swoich proroków» (non solum ait per prophetas suos), aby ktoś przez fałszywych proroków (ne quis a pseudoprophetis) poprzez pewne wyznania prawdy (per quasdam veritatis confessiones) nie został zwiedziony do jakiejś bezbożności (in aliquam impietatem seduceretur), lecz dodaje także (sed addit etiam): «w pismach świętych» (in sanctis scripturis) chcąc mianowicie pokazać (voleus utique ostendere), że literaturę pogańską (litteras gentium), przepełnioną zabobonnym bałwochwalstwem (su-

${ }^{18}$ Por. A. Eckmann, Dialog listowny św. Augustyna z Woluzjanem, RH 31(1983) z. 3, 63-89; tenże, Dialog św. Augustyna ze światem pogańskim w świetle jego korespondencji, Lublin 1987, s. 57.

19 Vergilius, Ecloga IV 4.

20 Por. Dz 17,28: „Bo w Nim żyjemy, poruszamy się i jesteśmy, jak też powiedzieli niektórzy z poetów: «Jesteśmy bowiem z jego rodu»". Jest to tekst z hymnu Kleantesa (331-232 prz. Chr.), filozofa ze szkoły stoickiej. 
perstitiosae idololatriae plenissimas) nie dlatego (non ideo) należy uważać za świętą (sanctas haberi oportere), że w niej znajduje się coś, co odnosi się do Chrystusa (quia in eis aliquid, quod ad Christum pertinet, invenitur)". ${ }^{21}$

Natomiast List 137 św. Augustyna do Woluzjana, wybitnego poganina, ma za temat tajemnicę wcielenia jako fundamentalną prawdę chrześcijańską. Wśród mnóstwa argumentów św. Augustyna w tym liście znajduje się także argument oparty na cytatach z IV eklogi Wergiliusza, interpretowany z odniesieniem do Chrystusa:

„Nunc ergo, quod Maro ait et omnes videmus, amomum Assyrium vulgo nascitur $^{22}$. Quod autem ad adiutorium gratiae pertinet, quae in Christo est, ipse est omnino,

«quo duce, si qua manent sceleris vestigia nostri, inrita perpetua solvent formidine terras ${ }^{23}$.

„Teraz więc wszyscy także widzimy to, co Maro mówi:

... "powszędy róść asyryjski balsam ci będzie».

To zaś odnosi się do pomocy łaski, która jest w Chrystusie, On sam w ogóle jest Tym,

«Pod Którego wodzą znikną, jeżeli zostały występków

Naszych ślady, i świat od wiecznej trwogi uwolnią»"24.

Zarówno więc w Komentarzu na List św. Pawła do Rzymian, jak i przede wszystkim w Liście 137 do Woluzjana, który odznaczał się wielką znajomością kultury pogańskiej, św. Augustyn mocno podkreśla, że byli nie tylko święci prorocy z narodu żydowskiego, którzy wypowiadali się w Piśmie Świętym na temat przyjścia na świat Chrystusa, ale byli także prorocy nie należący do Boga, prorocy pogańscy, ,u których znajdują się także pewne zapowiedzi”, jak to jest mowa także o Sybilli. W te zapowiedzi pogańskich proroków i w proroctwo Sybilli, które zdaje się odpowiadać i pasować do zapowiedzi o nadejściu królestwa naszego Pana, Jezusa Chrystusa, nie wierzyłby łatwo św. Augustyn, jak sam oświadcza, gdyby wiersza o pojawieniu się ostatniego czasu kumejskiej pieśni nie umieścił Wergiliusz w swojej IV eklodze.

W obszernej i wnikliwej analizie teologicznej przede wszystkim, i filologicznej Listu 137 św. Augustyna do Woluzjana, zwłaszcza rozdziału 12, ks. Eckmann słusznie wnosi, że ,zdaniem Augustyna sprawdza się to, co powiedział Wergiliusz" 25 . Słuszny także jest wniosek, że „profetyzm nie jest tylko przy-

21 Expositio ad Romanos inchoata 3,2-5, CSEL 84, 147-148.

${ }^{22}$ Por. Vergilius, Ecloga IV 25: „occidet; Assyrium vulgo nascetur amomum”.

23 Por. Vergilius, Ecloga IV 13-14:

„te duce, si qua manent sceleris vestigia nostri,

inrita perpetua solvent formidine terras".

${ }^{24}$ Epistula 137, 12, CSEL 44, 113-114.

25 A. Eckmann, Dialog listowny św. Augustyna z Woluzjanem, art. cyt., s. 82; tenże, Dialog św. Augustyna ze światem pogańskim, dz. cyt., s. 127. 
wilejem samych «świętych proroków», którzy wypowiadali się w Piśmie Świętym, ale znajduje się go także u filozofów, poetów i innych pisarzy w miarę, jak oni uczestniczą w prawdzie. [...] Nadzieją przyszłego pośrednika były przepełnione wszystkie kultury i praktyki pogańskie... [Chrystus] przyszedł potwierdzić swoją powagą wszystkie prawdy wypowiedziane przed Jego przyjściem, nie tylko przez proroków, ale także przez filozofów, poetów i wszystkich pisarzy, chociaż wiele prawd w ich dziełach jest pomieszanych z błędem"26. Na tę samą myśl zwrócił także uwagę w recenzji monografii o Symbolu Apostolskim $u$ św. Augustyna autorstwa ks. Eckmanna ks. Janusz Mariański cytując słowa: „Wcielenie było zapowiedziane nie tylko przez świętych proroków, ale też przez pogańskich filozofów, poetów i pisarzy o tyle, o ile uczestniczyli oni w prawdzie" ${ }^{, 27}$.

Do proroctwa kumejskiej Sybilli w IV eklodze (w. 38-41, 28-30, 42-45, 21-22) Wergiliusza odwoływał się wcześniej także retor i filozof Laktancjusz (250-330) w słowach:

„Kiedy zaś po zniszczeniu (deletis) bezbożnych religii (religionibus impiis) i poskromieniu zbrodni (scelere compresso) ziemia będzie poddana Bogu (subiecta erit deo terra), wtedy:

38 «Również i żeglarz morza porzuci, a nawa sosnowa Wieźć ku wymianie towarów nie będzie, bo ziemia każdemu

${ }^{40}$ Wyda wszystko, co trzeba, bez trudu motyki i sierpa;

${ }^{41}$ Krzepki oracz już woły spod jarzma na karku uwolni» wtedy także:

28 «Niwy wiotkimi kłosy pomału poczną się złocić,

Stodkie grona rumiane na dzikich głogach zawisną

${ }^{30} \mathrm{Z}$ twardych zaś dębów miód rosisty sączyć się będzie!»

42 «Wełna oduczy się barwność kłamanym udawać kolorem,

Sam bo baran na łące odmieni swe runo i już to

Krasą purpury, już to szafranem złocistym zabłyśnie,

${ }^{45}$ Pąs samorzutnie zaś wełnę okryje jagniąt na paszy»

21 «Same kozy przyniosą do domu mleczne wymiona

22 Pełne, a lwa ogromnego nie będą lękały się stada».

Poeta powiedział to według Proroctw Sybilli kumejskiej (secundum Cymaeae Sibyllae carmina) $)^{, 28}$.

Laktancjusz wyjaśnia, że prorocza zapowiedź pogańskiego poety dotyczy mającego nastąpić odnowienia świata i przyrody, które ma zaistnieć po zniszczeniu bezbożnych religii i poskromieniu zbrodni, a ziemia będzie poddana Bogu i zniknie trud z życia ludzi.

26 Tenże, Dialog listowny, art. cyt., s. 81-82; tenże, Dialog Augustyna ze światem pogańskim, dz. cyt., s. 127; tenże, Symbol Apostolski w pismach św. Augustyna, Lublin 1999, 65.

${ }_{27}$ Por. recenzję: A. Eckmann, Symbol Apostolski w pismach św. Augustyna, Lublin 1999 , ss. 256, w: AK 135(2000) t. 548, s. 184.

${ }^{28}$ Divinae Institutiones VII 24, 11-12, CSEL 19, 661. 
W świetle przytoczonych wypowiedzi, zwłaszcza św. Augustyna, o chrześcijańskiej interpretacji IV eklogi Wergiliusza, zapowiadającej narodzenie cudownego dziecięcia, wybawiciela, pośrednika Boga i ludzi, opartej na analizie Listu 137 do Woluzjana, trudno zgodzić się z tak zdecydowanie negatywnym osądem niektórych współczesnych uczonych, że ta interpretacja „nie budzi przekonania". Historyczny bowiem kontekst przedstawiony w eklodze IV Wergiliusza wskazuje jakoś na „czas najbardziej odpowiedni i określony przed wiekami przez samego Boga, a zapowiadany nie tylko przez 'świętych proroków', ale także przez pogańskich"29.

Twórczość Wergiliusza i innych poetów, pisarzy i filozofów antycznych znajdowała uznanie w kulturze chrześcijańskiej. Chrześcijanie bowiem wykorzystali wszystko, co dobre, piękne i prawdziwe. Kultura chrześcijańska tego nie negowała, ale przyswoiła sobie to wspólne dobro ogólnoludzkie. Nasiona kultury antycznej, prześwietlone wiarą i Pismem Świętym, chrześcijanie zasiewali i pielęgnowali. Czynił to także biskup Hippony Aurelius Augustinus. Eklogę IV Wergiliusza, zapowiadającą narodziny boskiego dziecięcia jako Zbawiciela, wykorzystał w wyjaśnianiu Woluzjanowi tajemnicy wcielenia. Taki argument literacki, obok innych, zwłaszcza filozoficznych, przedstawionych obficie w Liście 137 do Woluzjana, mógł trafić do wymagającego umysłu poganina o wysokiej kulturze i przekonać go o stosowności prawdy chrześcijańskiej o przyjściu na świat Zbawiciela. Wydaje się, że chrześcijańska interpretacja IV eklogi Wergiliusza zasługuje na przyjęcie, a nie na odrzucenie, jak to czynią niektórzy filologowie, do których nie przemawiają, jak widać, teologiczne, filozoficzne i biblijne argumenty św. Augustyna.

\title{
DE PRAENUNTIATIONE SALVATORIS ADVENIENDI IN IV ECLOGA VERGILII
}

\author{
(Argumentum)
}

In commentatione hac quattuor praenuntiationis Vergilianae interpretationes a Sophia Abramowiczówna (Vergilius, Bukoliki i georgiki, trad. et introductio Z. Abramowiczówna, Wrocław 1953, p. XXIV) allatae primum exponuntur: prima: puer mirabilis allegoriam aetatis aureae, pacis, Romae novae nascendae significat; secunda: puer hic divus dicitur: ,ille deum vitam accipiet” (v. 15), „,cara deum suboles” (v. 49), ,nova progenies caelo demittitur alto" (v. 7); qui puer salvator exspectatus dicitur; ,christianitas in eo Christum videre volebat”; tertia: puer ille

${ }^{29}$ Por. A. Eckmann, Symbol Apostolski w pismach św. Augustyna, dz. cyt., s. 64-65. 
oraculorum Sibyllae est incarnatio, quae ad „plenitudinem temporis veniendam” pertinet; quarta: ille puer homo stricte definitus in historia Romana est. Quattuor interpretationes allegoricae simili modo etiam a Maria Cytowska et Hanna Szelest (Literatura rzymska. Okres augustowski, Warszawa 1990, 77-78) referuntur. Interpretationibus his coniuncta est interpretatio christiana, quae praenuntiationem nativitatis Iesu Christi ab Aurelio Augustino inchoatam in ecloga quarta Vergilii videt. Quae interpretatio usque ad decimum sextum saeculum vigebat. Interpretatio christiana IV eclogae Vergilii apud Augustinum in Expositione ad Romanos inchoata 3, 2-5 (CSEL 84, 147-148) et in Epistula 137, 12 (CSEL 44, 113-114) invenitur. Quam Expositionem et Epistulam auctor tractationis huius in linguam Polonam transtulit et diligenter explicavit. Ad Oraculum Sibyllae in ecloga IV Vergilii (vv. 38-41, 28-30, 42-45, 21-22) Lactantius (Divinae Institutiones VII 24, 12, CSEL 19, 661) etiam appellavit. Illustratio haec et versus a Lactantio allati ab auctore disputationis in linguam Polonam quoque translati et breviter explicati sunt.

Interpretatio christiana eclogae IV Vergilii accipi potest. Exspectationes enim salvatoris cuiusdam inter cives Romanos saeculo primo exeunte ante Christum natum in diem percrebescebant. Rerum adiuncta in ecloga enarrata eiusdemque interpretatio christiana, praesertim a sancto Augustino facta, quaestionem propositam de praenuntiatione Christi Salvatoris unici adveniendi comprobant. 